\title{
DEMOGRAPHIC CHANGES AND FORMATION OF ETHNIC ENCLAVES
}

\author{
by
}

Irfan Ahmed Ansari, Bachelor of Engineering, Mehran University, Pakistan, 1990 And Master of Engineering, Asian Institute of Technology, Bangkok, Thailand, 1998

\author{
A Major Research Paper \\ presented to Ryerson University \\ in partial fulfillment of the requirements for the degree of \\ Master of Planning \\ in \\ Urban Development
}

Toronto, Ontario, Canada, 2010

(C) Irfan Ahmed Ansari 2010 
I hereby declare that I am the sole author of this major research paper.

I authorize Ryerson University to lend this paper to other institutions or individuals for the purpose of scholarly research.

Signature

I further authorize Ryerson University to reproduce this paper, in whole or in part, by photocopying or by other means, at the request of other institutions or individuals for the purpose of scholarly research.

$\overline{\text { Signature }}$ 


\section{Acknowledgments}

I feel greatly indebted to Dr. Sandeep Agrawal, my research supervisor, for his unremitting guidance which enabled me to complete this work. His support encouraged me to tide over a number of difficulties faced during the pursuance of this study. The completion of this work would not have been possible without his scholarly advice at all stages of the study.

My appreciation goes to Prof. Lawrence Altrows for being the Second Reader for my MRP and for his valuable time and input that he provided in this project.

I owe special thanks to my family, my wife and my children, who remained supportive and patient and allowed me time to complete my paper and the master studies. 


\title{
DEMOGRAPHIC CHANGES AND FORMATION OF ETHNIC ENCLAVES
}

\author{
(C) Irfan Ahmed Ansari, 2010 \\ Master of Planning \\ in \\ Urban Development \\ Ryerson University
}

\begin{abstract}
Statistics show that South Asian and Chinese ethnic enclaves had residential mobility rates of 54.5 percent and 46.5 percent respectively during 2001-2006 against the average of 44.9 percent for the Toronto CMA. This paper explores the implications of higher proportion of movement of Asian population in some selected ethnic neighbourhoods in Toronto. Why ethnics move into ethnic enclaves; why they move out from ethnic enclaves; and what are the implications of such movement on municipal planning are some of the questions explored in this study. This paper also discusses some of the emerging themes such as increasing trend of concentration of Asian population, displacement of one ethnic population by other ethnic population; and a possible disconnection between the neighbourhood demography, services, and the municipal planning, which may require further investigation.
\end{abstract}

Key words: Ethnic neighbourhood, Toronto areas, population change, demography, municipal implications, ethnic displacement. 


\section{Table of Contents}

Acknowledgments iv

ABSTRACT ..

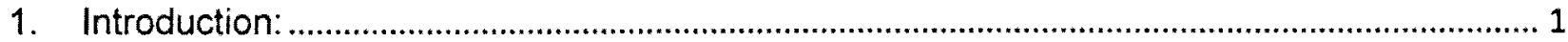

2. Research Method and rationale for choice and research design: ...................................... 4

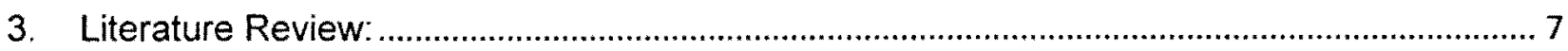

3.1 The formation of Ethnic Enclaves - Reasons for moving in: .................................... 7

3.2 Movement of ethnic population - Reasons for moving out: ..................................... 9

3.3 Understanding neighbourhoods and need for service delivery: ................................ 10

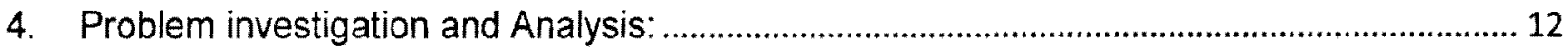

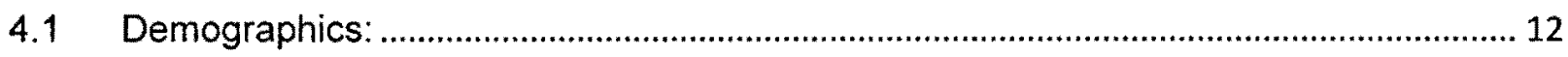

4.1.1 Thorncliffe Park Neighbourhood:..................................................................... 12

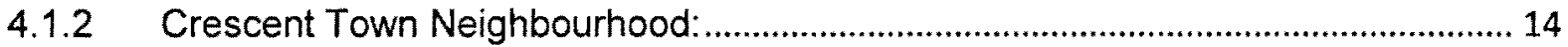

4.1.3 Milliken Neighbourhood, Scarborough: ........................................................... 15

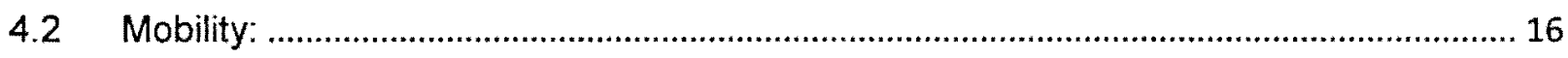

4.3 Change of ownership of selected properties (cluster of homes) in Milliken

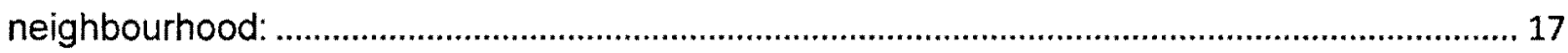

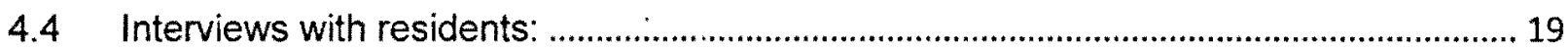

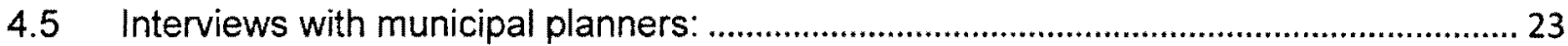

4.6 Interviews and email contacts with service providers (Neighbourhood offices,

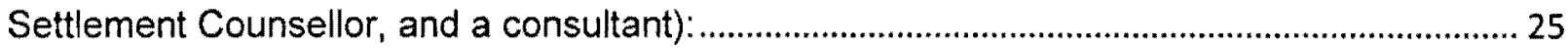

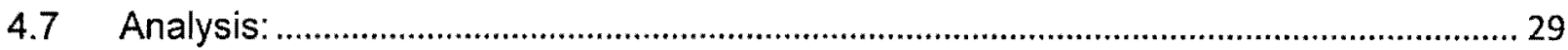

4.7.1 Reasons to move to and live/stay in an ethnic neighbourhood .............................. 30

4.7.2 What makes people move out of an ethnic enclave? Where do they move to? .... 31

4.7.3 Implications of inter-ethnic-enclave movements on planning: .............................. 33

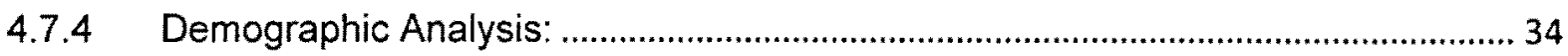

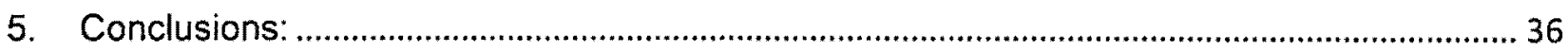

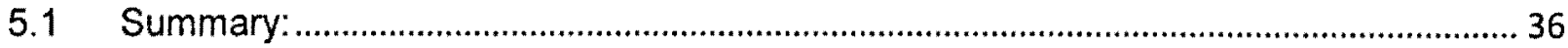

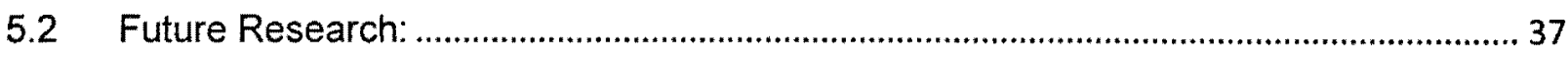

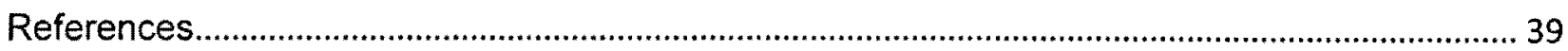

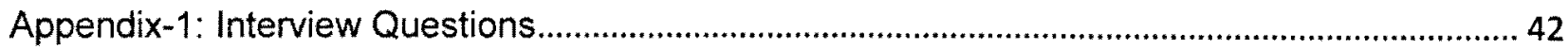

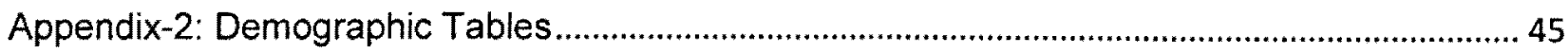




\section{Introduction:}

One of the legacies of immigrants in Toronto is the formation of distinctive neighbourhoods. From China Town to Little India and from Little Italy to Little Poland, today, new forms of enclaves have taken shape distant from the inner city locations of the traditional urban enclaves. Since early 70 s, Asian immigrants have most intensely mobilized and built their organizational resources for their social and economic wellbeing in many parts of Canada including Toronto municipal areas.

Scholars provide a number of studies that speak about ethnic enclaves and their formation, concentration of various ethnicities in different areas of Toronto CMA and other socio-economic studies related to ethnic immigrant populations in Toronto and GTA. Kumar \& Leung (2005) in their article on formation of ethnic enclaves have focused on ethnic immigrants' preferences of initial living to make a start in their new environment in a new country. Zucchi (2007), Qadeer (2003) and Siemiatycki (n.d) have talked about history of ethnic enclaves in Canada, residential segregation, cultural integration and citizenship and other characters of ethnic immigrants living in segregated places. It is however just recently that researchers have started to look in depth the trends of movement of people from ethnic minorities and effects of such movement on neighbourhood characteristics and services. One such article that depicts the recent settlement and movement trends in ethnic enclaves in Toronto comes from Qadeer, Agrawal and Lovell (2010), wherein they have, inter-alia, found that population of both Chinese and South Asian enclaves had higher rates of movement than the overall CMA average during 2001 to 2006 . The data, given in above article, shows that 54.5 percent South Asians and 46.5 percent of the Chinese enclaves moved during 
2001-2006 against the average of 44.9 percent for the CMA.

In order to explore this new phenomenon of higher proportion of movement of ethnic communities, this study attempts to go a step further by focusing on specific ethnic / Asian neighbourhoods and looking into the reasons of such movements within ethnic communities; how one ethnic community replaces / displaces people from another ethnicity/origin in a neighbourhood, what are the effects of this movement on the demography, community services and ultimately on municipal planning. This paper hence presents a longitudinal social and demographic analysis of selected neighbourhoods i.e. Thorncliffe Park neighbourhood, Crescent Town neighbourhood and Milliken neighbourhood, City of Toronto. The reason for the selection of these neighbourhoods are higher frequency of demographic changes in these neighbourhoods (for instances, $66 \%$ mobility rate of people in Thorncliffe Park [Boston, 2009] and 60\% Mobility rate in Crescent Town [Boston \& Meagher, 2007] during the period 2001-2006); ethnic characteristics of these neighbourhoods, and propensity of South Asian and Chinese immigrants to live in the areas of concentration of respective populations.

This paper starts with literature review on the topic, and then it uses data sources such as Statistics Canada and the neighbourhood profiles from City of Toronto to analyze the demographic trends in the selected neighbourhoods. It also uses an ownership data, acquired from Land Registry Office Toronto, of a selected cluster of 10 homes in Milliken neighbourhood to track the frequency of movement and demographic trends in this neighbourhood. Subsequently, drawing from the first hand data (interviews, phone, and email contacts), I explore the reasons of inward and outward 
movement of population within, to, or from the ethnic enclaves. I then discuss the process of movement in ethnic communities, and carryout a longitudinal analysis of neighbourhoods by acquiring the necessary neighbourhood data and comparing the data patterns at two points in time -2001 and 2006 . The results have been finally analyzed in the context of implications on municipal planning.

The findings suggest that the most influential factors for Asian population to move into and continue living in an ethnic enclave or move out from an ethnic enclave may include closeness to highway, closeness to schools, availability of larger/spacious apartments, availability of ethnic grocery stores, places of worship; friends and families; cheaper rents, language, ethnicity, nearby subway, and the same language. It also finds that the higher proportion of movement does not have any significant implications on municipal planning and services. However, the study indicates a need for rethinking the role of municipal planning, in terms of monitoring neighbourhood demographic changes and its possible implications, to avoid any service gaps. It is my hope that this paper will open new research avenues on the topic. 


\section{Research Method and rationale for choice and research design:}

Keeping in view the descriptive form and small size of data (17 interviews and text readings) used in the study, a mixed-method approach for research and analysis has been adopted that is dominantly qualitative and interpretive. The selection of research method was however made after looking into the examples from the studies on similar topic(s); such as Boston (2009) and Ghosh (2007); and reference material for research approaches, such as Neuman (2006) and Patton (1990).

Necessary data for this research study is based on the data collected from primary and secondary sources through qualitative interviewing, acquiring property ownership records from the registry office, and text reading, for typical interpretive research for identification of commonalities and thematic analysis. Given this approach, the study required 5 main elements.

1. Target neighbourhoods and relevant data;

2. Demographic and spatial patterns and a corresponding theory of change;

3. Sources of secondary Data;

4. Tools for acquiring primary data; and

5. Processes for assessing and interpreting data in the context of its implications on planning.

I adopted three approaches for data collection and analysis. Firstly, I conducted site visit of each of the three neighbourhoods to familiarize with the neighbourhood landscape, physical outlook, and any other indications to help focus and formulate the right direction of the research. Secondly, I carried out a rigorous review of literature from the secondary sources by looking at different scholarly articles, reports published by the relevant neighbourhood offices, and websites of Statistics Canada and the City of 
Toronto. Review of books, journals and previous research studies on ethnic enclaves was one of the main secondary sources for this study. By focusing on the demographic changes occurred in the selected three ethnic neighbourhoods, an initial analysis was carried out to provide a base for detailed analysis of the reasons and consequences of changing demographic patterns. In order to explore further, I selected a cluster of homes (10 Nos.) in one of the neighbourhoods (Milliken neighbourhood, Scarborough) and acquired their ownership records from the Metropolitan Toronto Land Registry Office to study the frequency and pattern of changes (mobility and demographics) of the neighbourhood for the given period of 2001-2006. The selection of homes was made on random basis, but preference was given to older homes to acquire maximum ownership transfer history. The mobility rate for the remaining two neighbourhoods (Thorncliffe Park and Crescent Town), being mostly the rental buildings, was obtained from the reports of the relevant neighbourhood offices and Stats Canada.

In the third approach, the information was gathered by means of personal interviews, email contact / conversation, and the narratives of key informants such as home owners and renters of these neighbourhoods. This included interviews of a total of 9 residents (three each from Thorncliffe Park and Crescent Town, two from Milliken neighbourhood, and one interview from a resident who lived in and moved between Thorncliffe Park and Crescent Town), one interview from the Director of one of the neighbourhood offices, one interview from a program coordinator of one of the neighbourhood offices, one interview from a Settlement Counsellor of one of the neighbourhoods, and four interviews from municipal community planners who deal with Milliken and Thorncliffe Park neighbourhoods. In addition to these interviews, a 
consultant (author of neighbourhood reports for both Thorncliffe Park and Crescent Town) also responded to the interview questions through email. Specific questions were asked to reveal the scenarios and reasons that make people live or leave ethnic neighbourhoods, how frequent is their movement into or out of these neighbourhoods, what can be their next location/neighbourhood if they decide to move, and the resulting change in services that they deem required because of frequent demographic changes. The purpose of the interviews from municipal planners was to know the extent that the municipal planning monitors the demographic changes of the neighbourhoods in Toronto for provision of neighbourhood services. Whereas, the information gathered through the interviews from representatives of the neighbourhood offices and from one of the consultants (author of relevant neighbourhood reports) was used to know their thoughts on the impact of high proportion of movement of population within these neighbourhoods. Interview questions are given at Appendix-1.

The analysis hence mostly relies on the primary data (interviews, email conversations, and property ownership data acquired from the Land Registry office) together with the study of secondary data (documents, case studies, and relevant reports and websites etc) to make a comprehensive case for useful results. 


\section{Literature Review:}

An approach to sustainable and equitable development requires well informed, purposeful courses of action by the state and other concerned social actors. To understand the changing patterns of ethnic enclaves, to ensure their essential socioeconomic wellbeing and to plan for possible resulting changes, it may be necessary to examine the process of evolution of ethnic neighbourhoods and movement of people to and from ethnic enclaves. Literature provides a number of theories related to formation and growth of ethnic enclaves and the issue has long been a part of scholarly articles. The available research however falls short of exploring the specific reasons, and resulting effects of high proportion of movement on ethnic neighbourhoods and that of the institutions and other facilities to support these neighbourhoods. The literature review is divided into three sections i.e. the formation of ethnic enclaves (Reasons for moving in), movement of ethnic population (Reasons for moving out), and understanding neighbourhoods and need for service delivery.

\subsection{The formation of Ethnic Enclaves - Reasons for moving in:}

Massey \& Denton (1985) describe that immigrants would initially cluster in typically poor neighbourhoods with high concentrations of co-ethnics, but that ethnic concentration should be temporary and would decline with socioeconomic improvement of immigrants' family lives. Once an immigrant family's socioeconomic status improves, they would move to a better and typically less segregated neighbourhood. This perception is also confirmed by Smith (2004), who mentions that new immigrants normally begin in enclaves and/or aging suburbs where housing is most affordable and then secondary moves are made in an outward direction to new and possibly more 
affluent suburban location. Boston \& Sean (2007) in a final report on Crescent Town Study also express a similar view point. The report mentions that people come to Crescent Town from all over the world to start a life in Canada. They get a good start in Crescent Town and then move on to neighbourhoods where they can buy a house. Alba \& Zhang (2002) refer the formation of ethnic enclaves a positive preference of immigrants for such areas. Authors view the ethnic enclaves as an alternative to assimilation for the immigrants. Similar conclusions also have been made by Zuchhi (2007), who sees the ethric enclaves of recent wealthy Chinese Immigrants as their places of choice, who wish to be in predominantly Chinese-speaking area with access to their own supermarkets and specialty store. Boyd (2009) has studied the ethnic enclaves with reference to linguistic similarity of different ethnicities and evolution and vibrancy of these enclaves depending upon how they facilitate to achieve socioeconomic benefits to ethnic immigrants. D'Addario et.al (2008) describes the residential concentration and ethnic segregation as result of mutual aid and the social support of religious groups for the newcomers with which they affiliate. Perrott \& Grant (2008) attribute the Asian influx in Markham as the work of developers, builders, and realtors as well as a manifestation of globalization and shift in immigration policy. They also see the ethnic concentration in Markham as transfer of people with particular kinds of technological skills to sites of employment. Kumar \& Leung (2005) point to the neighbourhood services and places of worship, along with many other reasons, as few of the factors influencing the change in residential and demographic patterns. Wayland (2007) mentions that most new arrivals in Canada find housing through the private rental market and their biggest housing related problem is affordability. Qadeer (2003) 
interestingly attributes the formation of ethnic enclaves to housing market trends; friends and family and word of mouth. He mentions that once the housing market is subdivided in smaller neighbourhood segments; it results in creation of ethnic cluster by displacing other groups. The concept is also reflected by Jackson (2004), who blames the housing market for creating segregation of rich and poor and racial groups in Canada. Myles \& Hou (2003) however presume the housing markets blind to ethnic differences where migrants select neighbourhoods on the basis of economic rather than on ethno-cultural considerations.

\subsection{Movement of ethnic population - Reasons for moving out:}

Myles \& Hou (2003) opine that immigrant families may exit from a low-income immigrant enclave in search of better housing, schooling and other neighbourhood qualities but a desire to expose children to ethnic cultural and social institutions could produce for them a preference to live in an ethnic neighbourhood. Haan (2005) concludes that most immigrants display more traditional patterns of locational attainment, starting their journey in an immigrant enclave and grádually, with upward socioeconomic mobility, move into the broader society over time. The concept is also referred to as a "way to spatial assimilation". Talking about the immigrant movement, Schellenberg (2004) and Renaud (2006) are of the opinion that most secondary mobility among recent immigrants occurs in three years after arrival, and very few immigrants move from one CMA to another during the resettlement process. Jackson (2004) opines that neighbourhood changes occur over time by people moving in and out, however very few sources of data follow people over long periods to watch for the trends and propensities. Qadeer (2003), Boston \& Meagher (2007), and a number of other authors 
and reports describe the improvement in socio-economic status of immigrants as the major reason to move out from an ethnic enclave.

\subsection{Understanding neighbourhoods and need for service delivery:}

Dobilas \& Battye (2005) in their report on 'Measuring Neighbourhood Vitality' indicate that currently Toronto has no comprehensive system of neighbourhood indicators, except for various examples of ways in which the city has been profiled using indicators, whereas the stability of neighbourhoods depends upon the rate of mobility of its residents (lower the mobility, more stable will be the neighbourhood). They conclude that Toronto is behind comparable cities and countries in terms of developing neighbourhood indicator systems. Government of Canada's Final Report of June 2009 on understanding Canada's $3 \mathrm{M}$ emphasizes on understanding the internal dynamics and everyday lived experience of ethnic enclaves and the people who live within them. Papillon (2002) argues for more consultation and more resources being transferred to municipalities for the development of programs that are responsive to the specific needs of the local neighbourhood populations. Wen et.al (2008) points out a need to further investigate the formation of ethnic enclaves (ethnoburb) as an evolving demographic trend of immigrant communities. Toronto District School Board's Demographic and Enrolment Overview (n.d) mentions that slight variances in demographic and enrolment variables over time have the potential to alter projected enrolments and populations. Therefore, there is a need to constantly reassess and monitor the trends to account for any future changes. Wallis et.al (2000) in their report for ISPR Consortium indicate that currently the research and identification of newcomer needs and planning for adequately responsive services are very fragmented and disconnected across the 
various immigrant groups that settle in Toronto. They, therefore, stress for more coordinated and collaborative strategies to provide the wide variety of settlement needs to the immigrant settlements. Schellenberg (2004) mentions that settlement of new immigrants has important implications for educational and other services and that the responsible institutions may need a well planned strategy to accommodate the immigrants' requirements. Taking this concept to a smaller scale, as per the scope of this study, when people move from an ethnic enclave, not only they may have an impact on the services and cultural requirements on their new neighbourhood but the spaces vacated by them may render their old neighbourhoods evolve differently to accommodate needs of their new occupiers. Though the recent study made by Qadeer, Agrawal and Lovell (2010) applies longitudinal approach to focus on the frequency and extent of movement in ethnic neighbourhoods / enclaves, the researches, as referred to in the literature review, fail to provide an in-depth picture of or theorize the reasons of such movements arising from constantly evolving and changing demographic patterns of ethnic enclaves at specific neighbourhood level.

To adopt a new way of looking into changing patterns of ethnic demography through study of specifically selected ethnic neighbourhoods / enclaves and to differ from the earlier work done by different scholars and researchers that provides the overall picture of the evolution and formation of the ethnic suburbs, this paper stretches further by zooming into selected three neighbourhoods; applies the already developed theories related to changing patterns of ethnic neighbourhoods; and attempts to answer the questions under the scope of this study. 


\section{Problem investigation and Analysis:}

This section looks at the major demographic characteristics of the three selected neighbourhoods, changes occurred in these neighbourhoods during the years 20012006; and provides a description of the interviews and email conversations with the residents, municipal planners, and the service providers (neighbourhood office, settlement office, and a consultant). The same is followed by the analysis of each of the data, leading to summary and conclusions.

\subsection{Demographics:}

The three ethnic neighbourhoods focused in this study are Thorncliffe Park, Crescent Town, and the Milliken neighbourhoods (Scarborough), City of Toronto; which have been selected on the basis of their ethnic characteristics (concentration of ethnic populations) and higher frequency of demographic changes. Stats Canada was used as the major source for acquiring the demographic details of the three neighbourhoods. It may be noted that the sum of the ethnic population in each of the data tables may not necessarily total to the overall population of that neighbourhood as only specific ethnic origin populations i.e. either related to Chinese and South Asian origins and / or long time ethnic residents of that neighbourhoods have been shown in the tables. The focus however goes to the analysis of the changing population trends of above mentioned ethnicities to track the frequency of movement and its implications on the provision of services and on municipal planning. The data tables are given at Appendix-2.

\subsubsection{Thorncliffe Park Neighbourhood:}

The demographic details of the neighbourhood were acquired from Statistics Canada using the Census Tract Numbers 194.01, 194.02, 194.03, and 194.04. The 
neighbourhood appears at S.No.55 of the neighbourhood profile list of City of Toronto.

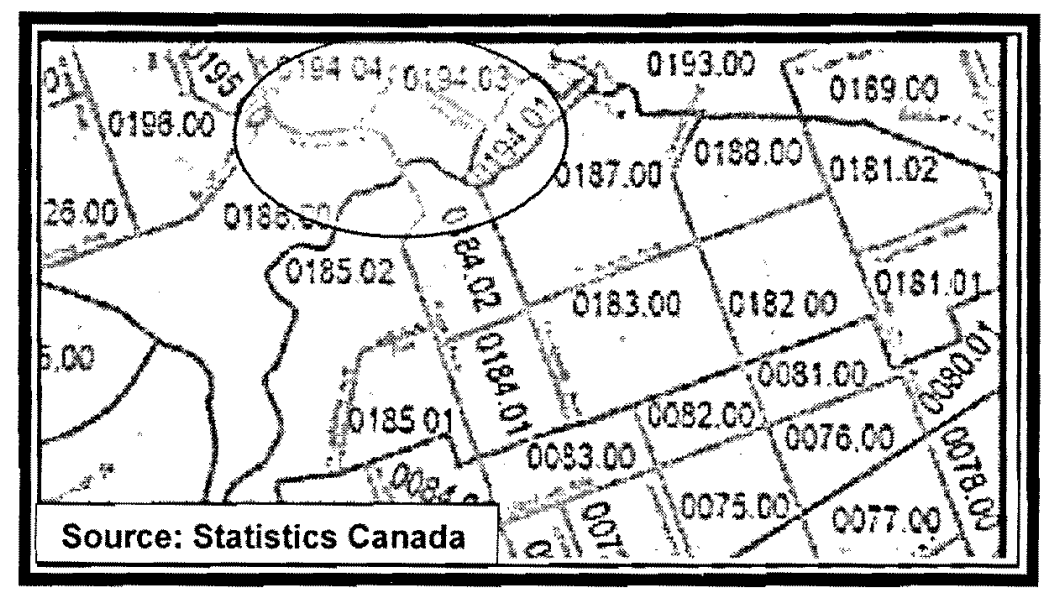

Table-1 shows that the overall population of Thorncliffe Park neighbourhood increased from 16400 to $17750(8.2 \%)$ during the years $2001-2006$. The major shifts in the population numbers relate to the population of Indians that increased from 1780 in 2001 to 4315 in 2006 (142\%); Pakistanis increased from 2130 in 2001 to 3515 in $2006(65 \%)$, people from Greece increased from 280 in 2001 to 575 in $2006(105 \%)$, the people from Afghanistan increased from 260 in 2001 to 1065 in 2006 (310\%), whereas the people from Guyana and Bangladesh decreased tremendously i.e. People from Guyana decreased from 315 in 2001 to only 10 in 2006 and the number of people from Bangladesh reduced from 190 in 2001 to $85(-55 \%)$ in 2006. The City of Toronto neighbourhood profile (2006) for Thorncliffe Park shows Urdu, Gujrati and Persian as three top most home languages of the neighbourhood whereas the percent of people speaking neither English nor French is $51.13 \%$. In terms of type of dwelling, there was a high percentage of rented housing in Thorncliffe Park i.e. $91 \%$ against only $9 \%$ of owned ones in 2006 . The owned housing however jumped by $1 \%$ since 2001 . The median and average incomes of the Thorncliffe Park neighbourhood were $\$ 18293$ and $\$ 25023$ against the Toronto CMA's numbers of $\$ 26754$ and $\$ 40704$ respectively, which 
shows lower income levels of the neighbourhood population as compared to the average for the City. On the basis of Canada's Low Income Cut-offs (LICO) of $\$ 27,745$ for 2006 (Stats Canada, 2007), the City of Toronto's neighbourhood profile estimates that $46.7 \%$ of private household lived below poverty level in 2006 . It may be noted that the median and average incomes of the neighbourhood are the average of the totals of the four census tract numbers as shown above.

\subsubsection{Crescent Town Neighbourhood:}

The demographic details of the neighbourhood were acquired from Statistics Canada using the Census Tract Numbers 180 and 190.01(Table: 2). The neighbourhood appears at S.No.61 of the neighbourhood profile list of City of Toronto.

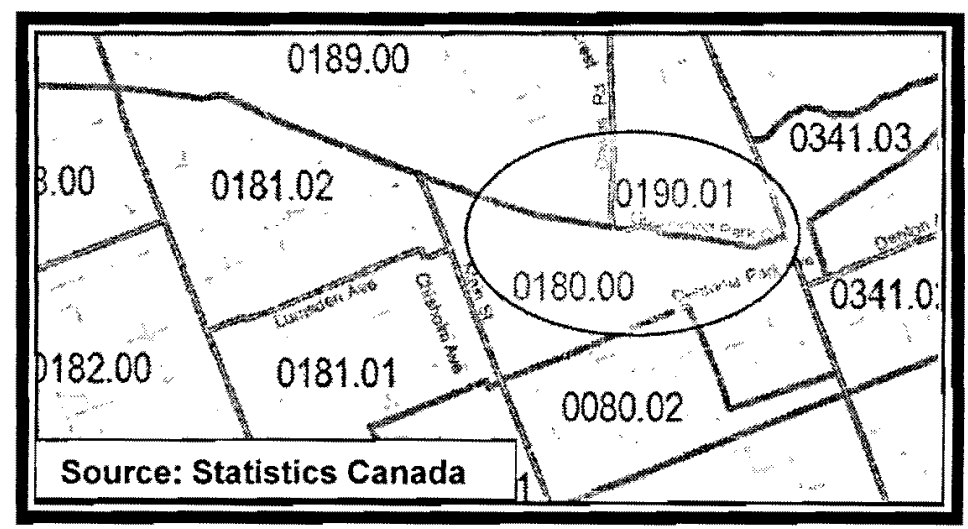

Though the overall population of Crescent Town has seen a considerable decrease i.e. from 16170 in 2001 to 14985 in $2006(-7.3 \%)$; its South Asian and Chinese population has increased from 4255 in 2001 to 6560 in $2006(54 \%)$. If seen carefully, the Chinese, Indian and the Bangladeshi population has increased noticeably; whereas the number for people from Sri Lanka and Pakistan show a decrease by about $50 \%$ each during the period from 2001-2006. The City of Toronto neighbourhood profile (2006) for Crescent Town neighbhourhood shows Bengali, Chinese and Urdu as three 
top most home languages of the neighbourhood, whereas the percent of people speaking neither English nor French is $41.13 \%$. The percentage of rented housing remained higher in the neighbourhood i.e. $64 \%$ against the owned housing of $36 \%$ during 2006 . The rentals however decreased by $3 \%$ since 2001 . The median and average incomes of the Crescent Town neighbourhood were $\$ 19450$ and $\$ 24442$ against the Toronto CMA's numbers of $\$ 26754$ and $\$ 40704$ respectively which shows lower income levels of the neighbourhood population as compared to the average for the City. At the individual household level, $34.5 \%$ households were below poverty level (i.e. below cut-off point of $\$ 27745$ ). The neighbourhood is one of the 13 priority areas, among other factors, due to its income indicators. It may be noted that the median and average incomes of the neighbourhood are the average of the totals of the two census tract numbers as shown above.

\subsubsection{Milliken Neighbourhood, Scarborough:}

The data for this neighbourhood was obtained from Statistics Canada using the Census Tract Numbers $377.06,377.07,378.18,378.19,378.20,378.21$, and 378.22

(Table 3). The neighbourhood appears at S.No.130 of the neighbourhood list of City of Toronto.

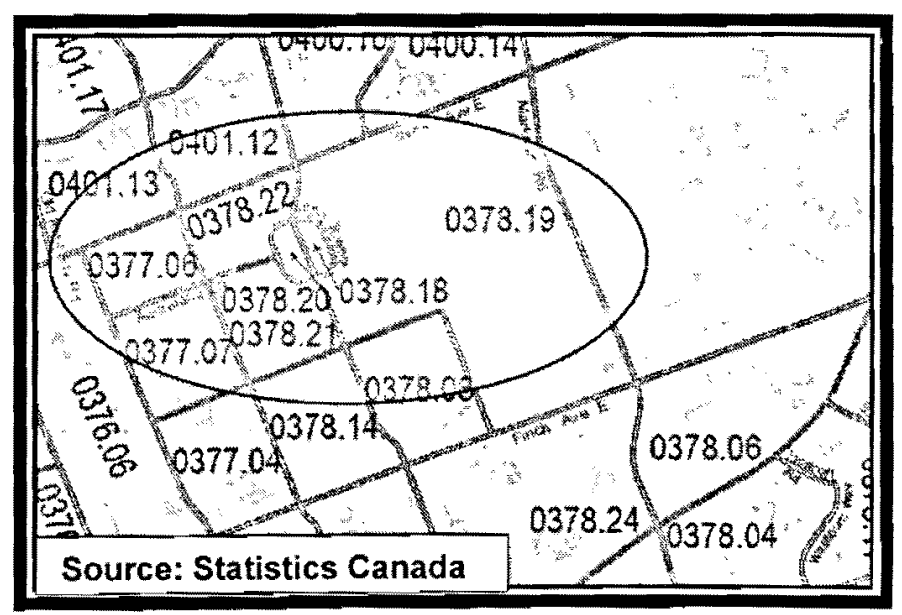


Similar to the Crescent Town Neighbourhood, though the overall population of Milliken neighbourhood, Scarborough decreased from 26690 in 2001 to 26140 in 2006 (-2\%), its Chinese and South Asian population increased from 13080 in 2001 to 20600 in 2006 (i.e. by $57.4 \%$ ). The major increase can be observed in the people of Chinese, Indian, and Sri Lankan origins; whereas the population of Pakistanis and Bangladeshis in this neighbourhood declined during the same period. The City of Toronto neighbourhood profile (2006) for Milliken neighbourhood (Scarborough) shows Chinese, Tamil and Tagalog (Filipino) as three top most home languages of the neighbourhood, whereas the percent of people speaking neither English nor French is $61.3 \%$. The percentage of owned housing remained higher in the neighbourhood i.e. $86 \%$ against the rented housing of only $14 \%$ during 2006 . The rentals however declined by $5 \%$ since 2001. The median and average incomes of the Milliken neighbourhood (Scarborough) were $\$ 17031$ and $\$ 24488$ against the Toronto CMA's numbers of $\$ 26754$ and $\$ 40704$ respectively. Though the figures for average and median income for the neighbourhood do not vary much from rest of the two neighbourhoods, the City of Toronto's neighbourhood profile shows that the percent of private household below poverty level was $26.8 \%$ in 2006 i.e. much lower than the household poverty levels of Thorncliffe Park and Crescent Town. It may be noted that the median and average incomes of the neighbourhood are the average of the totals of the seven census tract numbers as shown above.

\subsection{Mobility:}

In 2006, nearly half of the city of Toronto's population had changed their address in the five years since the 2001 Census. Of those who moved, $63 \%$ moved within the 
city. Among the remaining $37 \%$ of movers, 250,000 arrived from another country (City of Toronto, 2007). The moving rate of the population of Crescent Town over a period of five years is almost a $60 \%$ (Boston \& Meagher, 2007), whereas the mobility rate of Thorncliffe Park residents for the five year period is quoted to be $66 \%$ (Boston, 2009). The mobility rate of Milliken Neighbourhood Scarborough is found to be $38 \%$ (Stats Canada, 2001-2006).

\subsection{Change of ownership of selected properties (cluster of homes) in Milliken neighbourhood:}

As mentioned in above sections, a cluster of 10 properties (homes) was selected to look at the change of ownership details for last five years. It may be noted that the ethnicity of the property owner(s) is known based upon a guess apparently from the names of the owner(s) or transferee(s). A series of homes was selected on random basis during a site visit of the neighbourhood, whereas the data of ownership was acquired from Toronto Land Registry Office. The dates of first ownership show that the homes were built between 1991 and 1993. A summary of the ownership change, as extracted from the data, is given below:

\begin{tabular}{|l|l|l|l|l|l|}
\hline S\# & $\begin{array}{l}\text { Address of } \\
\text { Property }\end{array}$ & $\mathbf{1}^{\text {st }}$ Ownership & $\mathbf{2}^{\text {nd }}$ Ownership & $\mathbf{3}^{\text {rd }}$ Ownership & $4^{\text {Ownership }}$ \\
\hline 1 & $\begin{array}{l}\text { Street } \\
\text { Sthcott }\end{array}$ & $\begin{array}{l}\text { Chen, Zhi Liang, Li, } \\
\text { Feng Tuan } \\
28^{\text {th }} \text { Nov 1991. }\end{array}$ & $\begin{array}{l}\text { Ho, Sik Wah; Lam, } \\
\text { Shuk Ying } \\
10^{\text {th }} \text { May 1994 }\end{array}$ & $\begin{array}{l}\text { Kung, Anita } \\
\text { Hui Tung; } \\
\text { Kung, Bradley } \\
\text { Cheung Hay } \\
30^{\text {th }} \text { Aug 2007 }\end{array}$ & \\
\hline 2 & $\begin{array}{l}\text { 16 Ashcott } \\
\text { Street }\end{array}$ & $\begin{array}{l}\text { Chan, Wah Kin Ricky } \\
26^{\text {th }} \text { March 1992 }\end{array}$ & $\begin{array}{l}\text { Chung, Chi Cheng; } \\
\text { Chung, Lin Kar Pao } \\
8^{\text {th }} \text { Aug 1997 }\end{array}$ & & \\
\hline
\end{tabular}




\begin{tabular}{|c|c|c|c|c|c|}
\hline 3 & $\begin{array}{l}18 \text { Ashcott } \\
\text { Street }\end{array}$ & $\begin{array}{l}\text { Yung, Suet Ying; } \\
\text { Leung, Ting Wai } \\
20^{\text {th }} \text { May } 1992\end{array}$ & $\begin{array}{l}\text { Hsu, Tsu Long; Hsu, } \\
\text { Huang Chu Chua; } \\
\text { Huang, Chu Long; and } \\
\text { Mo, Jinli } \\
5^{\text {th Dec } 1994}\end{array}$ & $\begin{array}{l}\text { Rodrigues, } \\
\text { Angelo; and } \\
\text { Rodrigues, } \\
\text { Fatima } \\
28^{\text {th }} \text { Aug } 2000\end{array}$ & \\
\hline 4 & $\begin{array}{l}20 \text { Ashcott } \\
\text { Street }\end{array}$ & $\begin{array}{l}\text { Wong, Man Chan; } \\
\text { and Tai, Yun Hing } \\
18^{\text {th }} \text { Dec } 1991\end{array}$ & & & \\
\hline 5 & $\begin{array}{l}22 \text { Ashcott } \\
\text { Street }\end{array}$ & $\begin{array}{l}\text { Cheng, Larry Kok } \\
\text { Kiong Liu, Linda Gi } \\
\text { Mei } \\
26 \text { Sep } 1991\end{array}$ & & & \\
\hline 6 & $\begin{array}{l}24 \text { Ashcott } \\
\text { Street }\end{array}$ & $\begin{array}{l}\text { Gonzales, Edgardo } \\
\text { and Gonzales Elmer } \\
12^{\text {th }} \text { July } 1993\end{array}$ & $\begin{array}{l}\text { Mohandas, Rajini and } \\
\text { Muragananthan, } \\
\text { Selvathy } \\
\text { 31st May } 2004\end{array}$ & & \\
\hline 7 & $\begin{array}{l}26 \text { Ashcott } \\
\text { Street }\end{array}$ & $\begin{array}{l}\text { Lai, Yik and Mok, } \\
\text { Chui } \\
25^{\text {th }} \text { Aug } 1993\end{array}$ & $\begin{array}{l}\text { Fan, Yan Ling and Fan, } \\
\text { Te Chung } \\
28^{\text {th }} \text { Jan } 2000\end{array}$ & & \\
\hline 8 & $\begin{array}{l}28 \text { Ashcott } \\
\text { Street }\end{array}$ & $\begin{array}{l}\text { Chau, Kan Kwun } \\
5^{\text {th }} \text { April } 1993\end{array}$ & $\begin{array}{l}\text { Lee, Chun Kee Anthony } \\
12^{\text {th }} \text { Sep } 1994\end{array}$ & $\begin{array}{l}\text { To, Lin To } \\
4^{\text {th }} \text { Aug } 1999\end{array}$ & $\begin{array}{l}\text { Guan, Ruhuan } \\
\text { and Hu, Gexing } \\
23 \text { Oct } 2001\end{array}$ \\
\hline 9 & $\begin{array}{l}30 \text { Ashcott } \\
\text { Street }\end{array}$ & $\begin{array}{l}\text { Li, Wing Hang } \\
21^{\text {st }} \text { Jan } 1992\end{array}$ & $\begin{array}{l}\text { Li, Wing Hang and } \\
\text { Poon, Ching Han }\end{array}$ & & \\
\hline 10 & $\begin{array}{l}32 \text { Ashcott } \\
\text { Street }\end{array}$ & $\begin{array}{l}\text { Ning, Robert and NG, } \\
\text { Pui-Kwai } \\
8^{\text {th }} \text { Oct } 1992\end{array}$ & $\begin{array}{l}\text { Shi, Wen Qin; and He, } \\
\text { Xi Jun } \\
16^{\text {th }} \text { June } 2009\end{array}$ & & \\
\hline
\end{tabular}

The analysis of the property ownership details shows that the ownership of $90 \%$ of the properties started with Chinese owners, whereas $80 \%$ of homes ultimately remained with the Chinese owners. This small sample of data for this neighbourhood indicates that the neighbourhood has been relatively stable and consistently holding/increasing Chinese population with lesser movement since early $90 \mathrm{~s}$. It may also be true because of the fact that the Scarborough saw a significant increase in Asian population in 1980's with leapfrogging of ethnic themed markets and plazas (Qadeer, 1998). Above data hence does not show any significant rate of movement in this neighbourhood for the period 2001-2006, being the focus of this study. 


\subsection{Interviews with residents:}

A total of 9 residents; three each from Thorncliffe Park and Crescent Town, two residents from Milliken neighbourhood, and one resident who moved back and forth from Thorncliffe Park to Crescent Town and then to Thorncliffe Park; were interviewed individually. This was the hardest part of the work that needed extra efforts and patience to explain the residents the purpose of the study and the nature of questions that they could agree to respond to. The selection of participants was random, however efforts were made to invite the people from Asian ethnic backgrounds to focus on and reveal the main causes and implications of the higher proportion of movement in Asian immigrant populations on the neighbourhood services and municipal planning. A summary of the responses to the main questions asked in the interviews for each neighbourhood is given below:

Thorncliffe Park

\begin{tabular}{|l|l|l|}
\hline S\# & \multicolumn{1}{|c|}{ Interview Questions } & \multicolumn{1}{c|}{ Responses } \\
\hline 1 & $\begin{array}{l}\text { How long have you lived in } \\
\text { this neighbourhood? }\end{array}$ & The responses ranged between 1-3 Years \\
\hline 2 & $\begin{array}{l}\text { What factors influenced you to } \\
\text { come and live in this } \\
\text { neighbourhood? }\end{array}$ & $\begin{array}{l}\text { - Community affiliation } \\
\text { - Close relatives / friends live here } \\
\text { - Major highways in reach } \\
\text { - Larger (spacious) apartments }\end{array}$ \\
\hline 3 & $\begin{array}{l}\text { What do you like about living } \\
\text { here? }\end{array}$ & $\begin{array}{l}\text { - Halal food/grocery and mosque are in close proximity. } \\
\text { - Easy access to Buses/Transit. }\end{array}$ \\
& $\begin{array}{l}\text { - Many necessities within walking distances } \\
\text { - Nearby (better quality) schools and compactness of } \\
\text { neighbourhood was priority mentioned by almost all } \\
\text { the participants. }\end{array}$ \\
\hline 4 & $\begin{array}{l}\text { What you do not like living } \\
\text { here? }\end{array}$ & $\begin{array}{l}\text { Increasing safety issues (some gang activities and } \\
\text { drug dealing have started to occur inside the } \\
\text { neighbourhood buildings). }\end{array}$ \\
\hline
\end{tabular}




\begin{tabular}{|c|c|c|}
\hline 5 & $\begin{array}{l}\text { Given all the available facilities } \\
\text { and services, do you find this } \\
\text { neighbourhood welcoming? }\end{array}$ & $\begin{array}{l}\text { The neighbourhood is welcoming from many angles. The } \\
\text { most part includes the community, language and the a } \\
\text { number of cultural activities (most of the times organized } \\
\text { by the area MP-Rob Oliphant), people have chance of } \\
\text { playing and meeting in the parks in summer days, no } \\
\text { major parking issues, religious events celebrated } \\
\text { regularly, a family atmosphere. }\end{array}$ \\
\hline 6 & $\begin{array}{l}\text { What changes have you seen } \\
\text { (positive or negative) in the } \\
\text { neighbourhood since you } \\
\text { came to live here? }\end{array}$ & $\begin{array}{l}\text { - No major changes } \\
\text { - Increased gang activities } \\
\text { - Improved building maintenance } \\
\text { - Increasing population of people from Afghanistan } \\
\text { (demographic change) }\end{array}$ \\
\hline 7 & $\begin{array}{l}\text { Have you or your family been } \\
\text { to any agencies/used any } \\
\text { programs or services in this } \\
\text { neighbourhood? }\end{array}$ & $\begin{array}{l}\text { - Attended citizenship test preparation classes } \\
\text { organized by TNO } \\
\text { - Attended multiple times, some events organized by } \\
\text { area MP } \\
\text { - People get individual invitation/pamphlets at home for } \\
\text { the events organized my MP but the events organized } \\
\text { by TNO remain unnoticed due to being not well } \\
\text { communicated to the residents of the neighbourhood. }\end{array}$ \\
\hline 8 & $\begin{array}{l}\text { Are there programs, services } \\
\text { or agencies that you would } \\
\text { like to have access to you and } \\
\text { your family and be available in } \\
\text { this neighbourhood? }\end{array}$ & $\begin{array}{l}\text { - Library is closed since long time and it should open } \\
\text { soon. }\end{array}$ \\
\hline 9 & $\begin{array}{l}\text { Would you refer to any of your } \\
\text { friends or relatives to come } \\
\text { and live in this } \\
\text { neighbourhood? }\end{array}$ & $\begin{array}{l}\text { - Yes, I will (one response) } \\
\text { - I plan to move by myself (Other response). } \\
\text { advantages of living here, but for referring to my } \\
\text { friends, I'm more worried about increasing safety } \\
\text { issues nowadays (Third response). }\end{array}$ \\
\hline 10 & $\begin{array}{l}\text { If moved from here, what } \\
\text { would be your most probable } \\
\text { location/neighbourhood? }\end{array}$ & $\begin{array}{l}\text { - My priority would be a mixed income and more stable } \\
\text { neighbourhood with even better schools (one } \\
\text { response) } \\
\text { - Depends where my job happens to be (it would be } \\
\text { anywhere near to my job place) - (Two responses) }\end{array}$ \\
\hline
\end{tabular}




\section{Crescent Town}

\begin{tabular}{|c|c|c|}
\hline S\# & Interview Questions & Responses \\
\hline 1 & $\begin{array}{l}\text { How long have you lived in } \\
\text { this neighbourhood? }\end{array}$ & The responses ranged between $1-2$ Years \\
\hline 2 & $\begin{array}{l}\text { What factors influenced you to } \\
\text { come and live in this } \\
\text { neighbourhood? }\end{array}$ & $\begin{array}{l}\text { - Nearby subway } \\
\text { - Same language, a sense of relating to neighbours. } \\
\text { - Easy access to grocery and other amenities }\end{array}$ \\
\hline 3 & $\begin{array}{l}\text { What do you like about living } \\
\text { here? }\end{array}$ & $\begin{array}{l}\text { - Many people from my own country. } \\
\text { - Halal food and grocery are just at the door step. } \\
\text { - Easy access to Buses/Transit. } \\
\text { - Very close school } \\
\text { - Cheaper rents } \\
\text { - Services provided at neighbourhood level (Crescent } \\
\text { Town Club and regular job fair by some agencies) }\end{array}$ \\
\hline 4 & $\begin{array}{l}\text { What you do not like living } \\
\text { here? }\end{array}$ & $\begin{array}{l}\text { - Increasing safety issues (some thefts already } \\
\text { happened in the apartments when people were on job, } \\
\text { some gang activities have started to occur in the } \\
\text { neighbourhood). } \\
\text { - Deteriorating building conditions and lack of } \\
\text { maintenance of specially the rental buildings. Some of } \\
\text { the Condo buildings, also offered on rent, are in better } \\
\text { shape. } \\
\text { - Less ownership of neighbourhood by the residents } \\
\text { because of being here for short tenure. }\end{array}$ \\
\hline 5 & $\begin{array}{l}\text { Given all the available facilities } \\
\text { and services, do you find this } \\
\text { neighbourhood welcoming? }\end{array}$ & $\begin{array}{l}\text { - Yes, the neighbourhood is good and welcoming, } \\
\text { people respect you and share values being of same } \\
\text { origin (one response) } \\
\text { - The neighbourhood is very welcoming - I haven't seen } \\
\text { so many services offered at door steps in any other } \\
\text { neighbourhood (Second response) } \\
\text { - Neighbourhood is good but the building conditions and } \\
\text { some safety issues giving people some hard time. }\end{array}$ \\
\hline 6 & $\begin{array}{l}\text { What changes have you seen } \\
\text { (positive or negative) in the } \\
\text { neighbourhood since you } \\
\text { came to live here? }\end{array}$ & $\begin{array}{l}\text { - Many more people coming from my own origin } \\
\text { (Bengali). } \\
\text { - Increasing thefts and safety issues. } \\
\text { - Worsening building maintenance }\end{array}$ \\
\hline 7 & $\begin{array}{l}\text { Have you or your family been } \\
\text { to any agencies/used any } \\
\text { programs or services in this } \\
\text { neighbourhood? }\end{array}$ & $\begin{array}{l}\text { - I visit the club sometimes. } \\
\text { - Availed settlement services in the initial days that I } \\
\text { moved in this neighbourhood }\end{array}$ \\
\hline
\end{tabular}




\begin{tabular}{|c|c|c|}
\hline & & $\begin{array}{l}\text { Some senior services available, but I / my family have } \\
\text { never used them yet. }\end{array}$ \\
\hline 8 & $\begin{array}{l}\text { Are there programs, services } \\
\text { or agencies that you would } \\
\text { like to have access to you and } \\
\text { your family and be available in } \\
\text { this neighbourhood? }\end{array}$ & $\begin{array}{l}\text { Some programs that monitor the cleanliness of the } \\
\text { neighbourhood / building and also some sort of } \\
\text { surveillance to ensure safety. }\end{array}$ \\
\hline 9 & $\begin{array}{l}\text { Would you refer to any of your } \\
\text { friends or relatives to come } \\
\text { and live in this } \\
\text { neighbourhood? }\end{array}$ & $\begin{array}{l}\text { - If the purpose is easy transit, I would love to, but will } \\
\text { let them know about the building conditions and safety } \\
\text { issues (one response). } \\
\text { - May be, but would prefer for them to rent in any of } \\
\text { condo buildings. }\end{array}$ \\
\hline 10 & $\begin{array}{l}\text { If moved from here, what } \\
\text { would be your most probable } \\
\text { location/neighbourhood? }\end{array}$ & $\begin{array}{l}\text { - Any neighbourhood near to halal / ethnic grocery and } \\
\text { place of worship. } \\
\text { - Any place near to subway and better schools } \\
\text { - Any place with easy access to transit. }\end{array}$ \\
\hline
\end{tabular}

\section{Milliken Neighbourhood, Scarborough}

\begin{tabular}{|c|c|c|}
\hline S\# & Interview Questions & Responses \\
\hline 1 & $\begin{array}{l}\text { How long have you lived in } \\
\text { this neighbourhood? }\end{array}$ & The responses ranged between $3-5$ Years \\
\hline 2 & $\begin{array}{l}\text { What factors influenced you to } \\
\text { come and live in this } \\
\text { neighbourhood? }\end{array}$ & $\begin{array}{l}\text { - Living near to Chinese people } \\
\text { - Same language, a sense of belonging } \\
\text { - Easy access to grocery and ethnic specific services. }\end{array}$ \\
\hline 3 & $\begin{array}{l}\text { What do you like about living } \\
\text { here? }\end{array}$ & $\begin{array}{l}\text { - Many people from my own country and same } \\
\text { language } \\
\text { - Relatively good schools } \\
\text { - Surrounding Chinese markets. } \\
\text { - Easy access to Highway. }\end{array}$ \\
\hline 4 & $\begin{array}{l}\text { What you do not like living } \\
\text { here? }\end{array}$ & $\begin{array}{l}\text { - Not a lot of services provided by the government } \\
\text { - Not a lot of activities for seniors. }\end{array}$ \\
\hline 5 & $\begin{array}{l}\text { Given all the available facilities } \\
\text { and services, do you find this } \\
\text { neighbourhood welcoming? }\end{array}$ & $\begin{array}{l}\text { - Yes, the neighbourhood is good, safe, many } \\
\text { neighbourhood related services and activities from } \\
\text { Chinese organizations. }\end{array}$ \\
\hline 6 & $\begin{array}{l}\text { What changes have you seen } \\
\text { (positive or negative) in the } \\
\text { neighbourhood since you } \\
\text { came to live here? }\end{array}$ & $\begin{array}{l}\text { - Mostly it is demographic change. Previously there } \\
\text { were many people from India and Sri Lanka, but now } \\
\text { there are many Chinese. } \\
\text { - Many new ethnic markets and shops opening up } \\
\text { around. }\end{array}$ \\
\hline
\end{tabular}




\begin{tabular}{|c|c|c|}
\hline 7 & $\begin{array}{l}\text { Have you or your family been } \\
\text { to any agencies/used any } \\
\text { programs or services in this } \\
\text { neighbourhood? }\end{array}$ & $\begin{array}{l}\text { - There are a number of Chinese organizations and } \\
\text { clubs who remain active in providing even settlement } \\
\text { services. } \\
\text { - A lot of cultural events that we participate in and enjoy. } \\
\text { - Rarely get a chance to hear about any government } \\
\text { services but haven't got a chance to participate. }\end{array}$ \\
\hline 8 & $\begin{array}{l}\text { Are there programs, services } \\
\text { or agencies that you would } \\
\text { like to have access to you and } \\
\text { your family and be available in } \\
\text { this neighbourhood? }\end{array}$ & $\begin{array}{l}\text { - Some programs or services specific to seniors are } \\
\text { badly needed in the neighbourhood. } \\
\text { - Some language programs with flexibility of timings } \\
\text { (evenings). }\end{array}$ \\
\hline 9 & $\begin{array}{l}\text { Would you refer to any of your } \\
\text { friends or relatives to come } \\
\text { and live in this } \\
\text { neighbourhood? }\end{array}$ & $\begin{array}{l}\text { - All responses were very positive to this question and } \\
\text { they wanted their friends and family members to } \\
\text { locate to this neighbourhood. }\end{array}$ \\
\hline 10 & $\begin{array}{l}\text { If moved from here, what } \\
\text { would be your most probable } \\
\text { location/neighbourhood? }\end{array}$ & $\begin{array}{l}\text { - Richmond Hill or Markham - because the homes are } \\
\text { new, more Chinese moving there, and home prices } \\
\text { will appreciate in future (one response) } \\
\text { - I will move to any neighbourhood as long as I am } \\
\text { close to Chinese community and better schools are } \\
\text { not far from home (second response) }\end{array}$ \\
\hline
\end{tabular}

\subsection{Interviews with municipal planners:}

A total of four municipal planning staff was interviewed during the study process.

The planning staff that were interviewed included a senior planner (North Section of Community Planning, Scarborough District), a planning manager (North Section of Community Planning section), a Senior Planner (East Section, Community Planning North York District), and an Assistant Planner (Community Planning, North Section). The selection of the planning staff for interviews was random and mostly depended upon the willingness and availability of time with the planners.

Though the interviews with the planners were conducted on individual basis, the response / viewpoint of the planners in all the four interviews remained the same without any major variations. The general response to questions regarding any impact 
of high proportion of movement of ethnic communities on municipal planning or provision of services was that municipal planners do not plan differently for any specific neighbourhood(s) as the demand for different needs arising from demographic shifts may not relate to or have very less relationship to the services provided by the relevant municipality. For any location or neighbourhood, the service delivery model remains the same and that would be, by no means, ethnic specific. One of the planners explained that there can be two types of demands for services - (i) Soft services i.e. Schools, Community Services etc, and (ii) Hard services i.e. Water supply / Sewer, Transportation, housing etc. Both of these types of demands can be general for any type of demography. However, demand of services due to the change in demographics can hardly have any implications on built form or built environment to trigger planning/municipal action. Commenting on the Thorncliffe Park, a planner mentioned that there were no major development applications in pipeline for this neighbourhood and also there had been no major investment on this neighbourhood since many years. He also mentioned that the neighbourhood might be facing a challenge of population influx of beyond its designed capacity. There may also be resulting challenges to TDSB, which is planning more portables/class rooms, due to increasing number of children being enrolled on daily basis. On a question regarding monitoring of demographic changes, a planner responded that municipal planning do not monitor or collect any demographic statistics, unless otherwise triggered by requirement of official plan or secondary plan review due to any application of changes in built form or any major development intervention. The municipal planning, otherwise, relies on the five year statistics by the Stats Canada for its development initiatives. Regarding the need of 
service delivery specific to the population, the planner(s) replied that most of the services; such as health, settlement for new comers, employment \& training etc; come under the purview of provincial or federal government. The private, not for profit or contract agencies however do their own visioning and move to the neighbourhoods where they find the requirement of their services and potential of the neighbourhood to utilize them.

\subsection{Interviews and email contacts with service providers (Neighbourhood offices, Settlement Counsellor, and a consultant):}

This section summarizes the interviews made with a services provider (Settlement Counsellor), a representative of neighbourhood office (Thorncliffe Park), a representative of Crescent Town Club (CTC), and an email correspondence with a consultant (author / coauthor of two of the reports each pertaining to Crescent Town and Thorncliffe Park neighbourhood).

The interview with the representative of CTC and also an interview with the Settlement Counsellor at Crescent Town provided thorough information of the neighbourhood programs and services available for the community. The Crescent Town Neighbourhood is blessed with a number of community and social services offered by the CTC and some of other services providers (partners). These include swimming pool \& sports; recreational programs for children and youth; preschool programs; programs for seniors (including ones specific to Bengali community); community access programs and computer access facilities. Other services available from the settlement office and some other organizations include LINC classes, provision of legal advisory services twice a month, a weekly job squad event, nutrition program, and some of the other 
similar programs/activities. The participation rate of neighbourhoods in availing these services normally remains high (around more than $60 \%$ ). The CTC finds the neighbourhood welcoming in terms of its support for the community; its multicultural and multiethnic characteristics; closeness to subway line, affordable rents, school on doorsteps, and a very diverse and compact neighbourhood. Whereas the main challenges are seen as higher turnover rate / moving rate, more people per apartment than the standard criteria, meeting the expectations of the residents in provision of services within limited resources, creating partnerships with other organizations, and the extended times required to go through the processes for acquiring support and resources for social services. On a question regarding needed improvements to make the neighbourhood even better, the representative of the CTC hoped to bring more comprehensiveness in services to cope with the demands, getting more community involved that is challenged by the higher moving rate, and working to get more resources for the community services.

The Settlement Counsellor provides services to the neighbourhood community, especially to newcomers for their needs assessment, career profiling, and future planning/employment issues. She had been serving in this neighbourhood for around three years and could speak a number of languages including Bengali, Urdu, and Hindi etc. She mentioned that three years before there was hardly any settlement service in the area but now four to five other agencies also provide the similar services in the neighbourhood (Such as Access Alliance, Wood Green etc.). She also notices that apart from dominating Bengali population; the new families coming into the neighbourhood also include some Pakistani, Indian and Czech families. Regarding the 
major issues of the neighbourhood, she indicated employment, deteriorating building conditions due to less maintenance, and safety issues the main concerns of the residents that she comes across through her clients.

The representative of the Thorncliffe Neighbourhood Office (TNO) provided a very thorough insight of the services, issues and challenges of the neighbourhood. He mentioned that the neighbourhood was very welcoming from different perspectives. Due to the existing population of South Asian community in the neighbourhood, the newcomers of South Asian origin feel a sense of immediate familiarity with the neighbourhood. This also provides them an initial contact of their community. The neighbourhood is a special place for Gujrati speaking people and they have adopted their living in Thorncliffe Park as a mini-village and get an essence of a similar community living in India. Currently the Afghanis are the most growing origin of the neighbourhood. The neighbourhood is more facilitating with reference to availability of shopping malls, streetscape, walkability, spatiality, transport \& communication, availability of places of worship (Mosque, Jammat khana for Ismailies, Greek Church etc), Halal food grocery store, nearest big box store etc. The same has resulted in the vacancy rate of the neighbourhood rental buildings lowest in the city. He indicated that the neighbourhood school played a major role in promoting the image of an attractive neighbourhood, but the school was facing a main challenge of over and above enrolments issue (around 5 new students are registered in the neighbourhood school showing the extent of influx of population in the neighbourhood). He also pointed out that the overall number of new immigrants in Canada and Toronto is decreasing but the same is increasing in Thorncliffe Park neighbourhood and the neighbourhood was 
becoming more permanent than its image of springboard community. Due to the lenient attitude of the building management regarding the number of people residing in a unit, the neighbourhood was facing challenges of chronic overcrowding. He however opined that combination of demographic, social, spatial, commercial, and economic features makes this neighbourhood more attractive and welcoming for new immigrants and South Asian Population.

The consultant, who replied the interview questions through email, works for linking agencies and institutions with the population groups that they are funded to serve, and the contextual research that identifies trends, patterns, characteristics that allow for effective engagement. He had the chance to meet with many residents of the Thorncliffe Park and Crescent Town neighbourhoods; conducting focus groups/joining existing meetings to explore their experiences. He worked for the TNO to facilitate a strategic planning process and to assist the organization in integrating a neighbourhood/community development approach into its governance and operations. He opines that the census data suggests high mobility rates in (inward and outward) of the Thorncliffe Park neighbourhood, and the stability of age distribution suggests an ongoing pattern of newcomer families staying for a few years and then moving on, being replaced by families of similar composition (relatively low and stable numbers of youth, and high numbers of young children). He pointed out that there was some anecdotal suggestion that there are less transfers out from high school during the school year, but there is not hard data to support this. Thorncliffe Park will however remain a receiving community and therefore the moving rate, in and out of the neighbourhood, may remain high. He considers a number of characteristics that make the Thorncliffe Park 
welcoming, which include available market rent housing, central location (Crescent Town even more so because of subway station) and ethno-specific religious, cultural and economic infrastructure. No ethnic specific services were identified that were abandoned due to demographic shifts, however, there is a requirement of new services, such as Afghan community has been requesting and provided with increased language and counseling services and the same were required for Spanish speaking residents similarly. In order to improve the quality of life in the neighbourhoods, the consultant has made a number of suggestions that include an appropriate, sustainable employment, recognizing skills, qualifications and experience derived on any soil; affordable, accessible child care; maximizing opportunities for children and youth to define and achieve career goals and build positive relationships - perhaps with an intercultural focus; pace and resources for ethno-specific and intercultural activities; violence against Women programs; and finally, there should be an initiative that recognizes the immigrants receiver "function" of Thorncliffe Park and Crescent Town. Intervention and supports specifically for newcomers to support them in their transition in, through and out of the neighbourhood, including longitudinal tracking.

\subsection{Analysis:}

Analysis of the data collected through literature review and the interviews from residents, municipal and service providers revealed a variety of and sometimes complex ideas of what makes a neighbourhood welcoming, what makes the ethnic / Asian populations to move in or move out of a neighbourhood, what are the reasons of high proportion of movement, and what can be the implications of such a frequency of movement on municipal planning. While there were a number of responses from the 
residents and other interviewees that were consistent with the contemporary theories of planning, the interview process also brought a number of new concepts which have not been discussed much or taken as the reasons of frequent demographic changes in the ethnic neighbourhoods. To keep with the scope of the study and the research questions, I have divided my analysis in 4 different sections, which are discussed in the light of literature review and responses of the interviewees, as below:

\subsubsection{Reasons to move to and live/stay in an ethnic neighbourhood}

The analysis of the interview data suggest that the major reasons for living in an ethnic neighbourhood(s), as described by interviewees include community affiliation, close relatives, friends, closeness to highway, closeness to schools, availability of larger/spacious apartments, ethnic food and groceries within walking distances, nearby subway, same language, affordable rents, living near to same ethnic population etc. One major influencing factor that the literature does not stress upon much but was given more importance by the participants was living somewhere or moving near to the work place. I would however prefer to discuss the same in next section of analysis. Above findings, also confirm the results of most of the previous studies made on the subject. Such as Qadeer (2003); Smith (2004), Kumar \& Leung (2005), and many others look at the availability of ethnic grocery stores, ethnic business concentrations, places of worship; friends and families; language, ethnicity, and other such reasons that attract the ethnic population to the specific neighbourhoods. Agrawal (2006) in his study on 'housing adaptation', which focused on Asian-Indian homeowners in Toronto finds that the choice of homeowners to live in a neighbourhood was primarily influenced by living in good, stable, and affluent neighbourhoods. On the other hand, literature, such as 
Jackson (2004) attributes housing markets, cheap rents and or minorities' decision to choose against assimilation as the influencing factors, whereas Harris (2008) finds interconnectedness of commodification of culture place-making, memory and city development in ethnic enclaves as some of the factors making ethnic population to come and continue their living in ethnic neighbourhoods.

\subsubsection{What makes people move out of an ethnic enclave? Where do they move to?}

The analysis of the interviews shows that desire for better schools/education for their children; to be near to job place; to get near to subway/transit; and to buy a home in an area where prices appreciate, may be some of the reasons that may influence ethnic population to move to another location. Observation of previous studies also indicates the similar reasons that make the ethnics move out from an ethnic enclave. Such as Smith (2004) indicate that immigrants make secondary moves in an outward direction to possibly more affluent suburban locations once time brings more experience, language and capital to the new immigrants. Some of the data, such as Stats Canada and neighbourhood profiles indicate that the mobility rate of the three neighbourhoods may be the result of influx of ethnicity causing displacement of another ethnicity, such as increase in number of Pakistanis and people from Afghanistan in Thorncliffe Park may relate to reduction in people from Bangladesh and Guyana.The same may be similar as Boustan (2010) exemplifies some of the neighbourhoods in USA where whites responded to black influx by leaving cities in a rate that each black arrival led to 2.7 white departures. Hence, increase in the population of one community compelling the other community shy away / move to other neighbourhood(s). 
Though different reasons, as already identified in the literature may well be valid, to some extent a different reason of moving out from an ethnic enclave found as part of this study (interviews), was getting close to job place. Literature, in some studies also indirectly touch upon the similar facts by saying that new immigrants do a secondary move within their first three years Schellenberg (2004), or, more closely, as Agrawal (2006) finds that some of the Asian-Indian homeowners wanted to be close to their partner's workplace, which influenced the choice of their neighbourhood. The reasons given for that move are however, to some or much extent, vary from the point of view of the participants of this study. One of the participants, who lived in Thorncliffe neighbourhood, moved to Crescent Town and moved back to Thorncliffe did his moving because of the change in his job and wanted to be close to his work place. When asked regarding the future relocation plans, the majority of the participants did mention proximity to their workplace as one of the deciding factors. It is clear from the literature, demographic data, and neighbourhood reports, that newcomers form a considerable part of the ethnic neighborhoods' and that they move within their initial years of settlement. If we connect this concept to the question where exactly they go and why do they go, location of employment can be the strongest factor that may influence a newcomer to move, and where to move. Another longitudinal study may however be needed to confirm the same. The second most important point was the affordable rents, followed by a reason to move to a place where other people of same origin lived. Hence, we may divide the reasons of outward movement of ethnic population (i) to a non-ethnic enclave: due to job location, better schooling, to reside in a mixed income neighbourhood with newer houses where the property values appreciate; and (ii) to 
another ethnic enclave: to move to an enclave where other people of same origin lived, affordable rents, and more spacious apartments/houses.

\subsubsection{Implications of inter-ethnic-enclave movements on planning:}

The analysis under this section mostly depends upon the literature review and the interviews of municipal planners as the interviews from the residents and the services providers do not provide any significant information on this issue. The interviews conducted with the representative of Thorncliffe Park Neighbourhood office and that of the municipal planners reveal that there are no different services at the municipal level provided to ethnic enclaves. It was however noted that the ethnic organizations, any nonprofit organizations, and religious or social organizations, at their level may come up with the provision of ethnic specific or religious services which do not have any impact on the municipal planning. The literature review and the interviews also did not indicate any closure or abandonment of any ethno-specific services due to change in demography of the ethnic neighbourhoods. However, there was an evidence of requirement of new services, such as Persian speaking counsellor, ESL classes, and services for Chinese seniors in the relevant neighbourhoods. These again may not have any impact on the municipal planning. On the other hand, the topic is a not adequately addressed in the literature. The literature as well as the interviews with planners show that the movement of people to or from ethnic enclaves has relatively insignificant impact on the provision of services or planning. The only implication that the demographic changes may have, appears to be on the school / School Board. Kumar, Qadeer and Prasad (2006) in their study on 'Immigrants' Needs and Public Service Provisions in Peel Region" conclude that immigrants have almost similar service needs 
as a public at large and ethnic enclaves do not have any impact on the demand for services. The interviews with the municipal planners however indicated a major disconnect between the neighbourhood environment, demography, and services and that of the municipal planning. Though the variation in the number of neighbourhood population can have major effects on traffic volume, requirement of transit, requirement of school space, parks and open spaces; the monitoring of the neighbourhoods by the municipal planners remain restricted to the five year statistics and remains silent until and unless triggered by any major development applications or requirement of the review of secondary plans.

\subsubsection{Demographic Analysis:}

The demographic data of the three neighbourhoods shows that there has been a continuous increase in the Asian population in these neighbourhoods (irrespective of the overall population growth). It is worth noting that apart from ethnicity, the trend of concentration of population on the basis of same language / country is also taking place. Such as, people of Bangladeshi descent in Thorncliffe Park, whose population increased from just 20 to 190 during 1996-2001, suddenly decreased to 85 in 2006 . At the same time, the number of people from Bangladesh increased in Crescent Town from 1100 in 2001 to 1240 in 2006 . It may be noted that Bangladeshis are already a dominant ethnic group in Crescent Town. On the other hand, the number of people from Pakistan declined in Crescent Town from 1035 in 2001 to 645 in 2005, whereas the population of Pakistanis increased in Thorncliffe Park from 2130 in 2001 to 3515 in 2006. It may again be noted that people from Pakistan are one of the dominant groups in Thorncliffe Park. The people of Afghan origin has been the fastest growing 
community in Thorncliffe Park and the number of people from India has been increasing at fast pace in both Thorncliffe Park and Crescent Town neighbourhoods. In Milliken neighbourhood, Chinese have been a dominating as well as fastest growing community.

Considering the above, one may observe two major emerging trends - (i) There has been an increasing trend of segregation on the single origin/language basis; and (ii) There is a possible trend of displacement of one ethnic community by other e.g. people from Bangladesh moving from Thorncliffe Park to Crescent Town and the number of people of other origins, such as Pakistanis, decreasing from Crescent Town but increasing in Thorncliffe Park. This may however require another longitudinal study by following specific number of households from focused countries to see whether or not the increase or decrease in above ethnic communities is the result of inter-ethnicenclave movement and displacement on the similar pattern of 'white flight'. 


\section{Conclusions:}

\subsection{Summary:}

Recall, the major objectives of this study were to look at the factors that attract ethnic population to come and live in an ethnic enclave; the factors that make the ethnic population to move out from an ethnic neighbourhood to another ethnic or non-ethnic neighbourhood; and the implications of higher movement of the ethnic population on planning.

Analysis of the data in this study suggests that there are a number of factors that attract the ethnic populations, especially the new immigrants, to come and live in ethnic neighbourhoods. The primary factors may include availability of ethnic grocery stores, places of worship; friends and families; affordable rents, language, ethnicity, nearby subway, and the same language. The secondary factors are closeness to highway, closeness to schools, and availability of larger/spacious apartments. There are a number of other factors that could be found in the literature; such as mutual aid/social support from religious groups, market trends, and alternative to assimilation; however those could not be verified in this study. Then it is the safety, development of social ties, and the available job market that facilitates the people to continue their living in a neighbourhood. Findings of this study suggest two types of reasons that influence the ethnic population for an outward movement from an ethnic enclave - (i) to a non-ethnic enclave: due to change in job location, better schooling, to reside in a mixed income neighbourhood with newer houses where the property values appreciate; and (ii) to another ethnic enclave: to move to a neighbourhood where other people of same origin/language lived, more variety of ethnic grocery stores/malls, closer places of 
worship, more cultural activities, affordable rents, and more spacious apartments/houses. Previous studies, such as Qadeer (2003), Smith (2004), and Schellenberg (2004) also confirm the above findings.

Lastly, the study shows that there are apparently no different services at the municipal level provided to ethnic enclave, hence, indicating no significant effects of demographic changes on municipal planning. There may however be the effects on the settlement services and schools etc. The same also confirms the conclusions made by Kumar, Qadeer \& Prasad (2006) in their study on 'immigrant needs and public service provision in Peel Region'. The interviews with the municipal planners however indicated a possible disconnection between the neighbourhood population, demography, and services and that of the municipal planning.

\subsection{Future Research:}

As a focal point for social and demographic investigation, neighbourhoods provide a useful lens through which to examine wider socioeconomic processes. Understanding neighbourhoods in terms of how they function, their composition and how they grow in larger urban systems is important not orily for municipal planning but also for urban policy and decision making. And given the diversity that exists within Canadian cities, research and exploration of effective place-based policy may provide a profound understanding of the dynamics within and between the individual neighbourhoods impacting and/or impacted by the policy.

Based upon the findings of the study, further studies are suggested to comprehend and improve the role of municipal planning at neighbourhood levels. The studies may focus on: 
1. Rethinking the role of municipalities in providing required municipal services at neighbourhood level by adopting monitoring mechanisms that take into account the neighbourhood population, as the same can have major effects on traffic volume, requirement of transit, requirement of school space, parks and open spaces and may require municipal intervention.

2. The reasons of movement of Asian population with reference to their desire to live near to their job place or easy transportation and the new and emerging trends of segregation of ethnic populations on the single origin/language basis; and the displacement of one ethnic community by other, and confirmation and development of new theories on the topic.

3. The small sample analyzed in this study is a first and obvious limitation. It reflects the challenges in data collection. Many potential informants were uninterested in the project, fearing that their participation may affect their relations with the building management / neighbourhood organizations or services that they are using, despite reassurances that this would not be the case and the data regarding their identities would be confidential. In addition to the same, keeping in view the scope of the study, the factors such as economic status, income, health etc have not been made part of the analyses of this paper. Further study is therefore warranted to confirm the findings of this paper taking into account all the relevant factors / variables that could not be considered in this research paper. 


\section{References:}

Boyd, Monica (2009). Language at Work: The Impact of Linguistic Enclaves on Immigrant Economic Integration, Canadian Labour Market and Skills Researcher Network, University of Toronto (September 2009).

Boston, Tony (2009). Understanding Thorncliffe Park - Needs Assessment Report, November 2009, prepared for Thorncliffe Neighbourhood Office.

Boston, Tony \& Meagher Sean (2007). Crescent Town Study - Final Report of a Study Commissioned by the Crescent Town Club, November 20, 2007 (through Public Interest Strategy \& Communications).

Boustan, Leah Platt. (2010). Was Postwar Suburbanization "What Flight"? Evidence From The Black Migration, The Quarterly Journal of Economics, Vol. 125, No. 1, Pages 417-443 February 2010.

City of Toronto (2007). 2006 Census on Language, Immigration, Citizenship, Mobility/Migration, Toronto City Planning, Research \& Information, December 2007 http://www.toronto.ca/demographics/pdf/2006_lang_imm_citizenship_mobility _backgrounder.pdf

City of Toronto (n.d). Neighbourhood profiles. Retrieved from http://www.toronto.ca/demographics/profiles_map_and_index.htm

D'Addario, Silvia; Kowalski, Jeremy; Lemoine, Maryse; and. Preston, Valerie (2008). Finding Home: Exploring Muslim Settlement In The Toronto CMA, CERIS Working Paper No. 68, October 2008.

Dobilas, Geoffrey and Battye, Fraser (2005). Measuring Neighbourhood Vitality, Final Report, GHK International (Canada) Ltd., January 2005.

Ghosh, Sutama (2007). Transnational Ties and Intra-Immigrant Group Settlement Experience: A Case Study of Indian Bengalis And Bangladeshis in Toronto, GeoJournal (2007) 67:223-242.

Government of Canada (2009). Understanding Canada's "3M" (Multicultural, Multilinguistic and Multi-religious) Reality in the 21st Century, Final Report, PRI Project - Cultural Diversity (June 2009).

Haan, Michael (2005). Are Immigrants Buying to Get In? : The Role of Ethnic Clustering on the Homeownership Propensities of 12 Toronto Immigrant Groups, 1996-2001; Analytical Studies Branch Research, Statistics Canada, Paper Series Catalogue no. 11F0019MIE - No. 252.

Harris, Jenna Frances; (2008). Making District Del Sol: The Murals of Saint Paul's West Side, an Honors Thesis, History Department, Macalester College. 
Jackson, Andrew (2004). Home Truths: Why the Housing System Matters To All Canadians, Canadian Centre for Policy Alternatives, Canadian Housing and Renewal Association (CHRA).

Kumar, Sandeep. (2006). Housing Adaptations: A Study of Asian Indian immigrant homes in Toronto. Canadian Ethnic Studies Journal. Vol. XXXVIII No. 1.

Kumar, Sandeep \& Leung, Bonica (2005). Formation of an Ethnic Enclave: Process and Motivations, Plan (Summer, 2005).

Kumar, S; Qadeer, M and Prasad, Arvin (2006). Immigrants' Needs and Public Service Provisions in Peel Region, Plan Canada, June 2007.

Myles, John \& Hou Feng (2003). Changing Colours: Spatial Assimilation Theory and New Racial Minority Immigrants, University of Toronto and Statistics Canada (January 2003).

Massey, Douglas S. and Nancy A. Denton (1985). "Spatial Assimilation as a Socioeconomic Outcome." American Sociological Review. 50, 1: 94-106.

Mendez, Pablo (2008). Immigrant Residential Geographies and the "Spatial Assimilation" Debate in Canada 1997-2006. Centre of Excellence for Research on Immigration and Diversity, Metropolis British Colombia, Working Paper Series No. 09-07, September 2008.

Neuman, W. Lawrence, 2006. Social Research Methods: Qualitative And Quantitative Approaches, Sixth Edition, Pearson Education Inc., Library of Congress Cataloging-in-Publication Data.

Papillon, Martin (2002). Immigration, Diversity and Social Inclusion in Canada's Cities, Discussion Paper F-27 Family Network, December 2002, Canadian Policy Research Networks Inc. (CPRN).

Patton, Michael Quinn. 1990. Qualitative Evaluation and Research Methods, 2nd edition, London: SAGE Publications.

Perrott, Katherine and Grant, Jill (2008). Producing diversity in a new urbanism community: theory meets practice, published in Town Planning Review, Liverpool University Press, Volume 80, Number 3/May 2009.

Qadeer, Mohammad; Agrawal, Sandeep \& Lovell, Alexander (2010). Evolution of Ethnic Enclaves in The Toronto Metropolitan Area, 2001-2006.

Qadeer, Mohammad (2003). Ethnic Segregation in a Multicultural City: The Case of Toronto, Canada, Joint Centre of Excellence for Research on Immigration and Settlement - Toronto CERIS Working Paper No. 28.

Qadeer, Mohammad (1998). Ethnic Malls And Plazas: Chinese Commercial Developments in Scarborough, Ontario, Joint Centre of Excellence for Research on Immigration and Settlement - Toronto, Working Paper No. 3. 
Renaud Jean and Begin Karine (2006). The Residential Mobility of Newcomers to Canada: The First Months. Institute of Urban Studies, University of Montréal, Canadian Journal of Urban Research, Volume 15, Issue 2, Supplement pages 67-81.

Smith, Heather A (2004). The Evolving Relationship between Immigrant Settlement and Neighbourhood Disadvantage in Canadian Cities, 1991-2001. Research on Immigration and Integration in the Metropolis (RIM), Working Paper Series No. 04-20, October 2004.

Schellenberg, Grant (2004). Trends and Conditions in Census Metropolitan Areas: Immigrants in Canada's Census Metropolitan Areas, Business and Labour Market Analysis Division, Statistics Canada.

Siemiatycki, Myer (n.d). Immigration, Diversity and Urban Citizenship in Toronto. Joint Centre of Excellence for Research on Immigration and Settlement (CERIS), published in Canadian Journal of Regional Sciences, Vol. XX No.1,2 Spring-Summer / Printemps-Été 1997.

Stats Canada (1996-2001). Canadian 2001 Census Profile (Census Tract level). Retrieved from http://dc1.chass.utoronto.ca.ezproxy.lib.ryerson.ca/cgibin/census/2006/displayCensusCT.cgi?c=eth

Stats Canada (2001-2006). 2006 Census / Language, immigration, citizenship, mobility and migration. Retrieved from

http://dc1.chass.utoronto.ca.ezproxy.lib.ryerson.ca/census/2001_ct_cit.html

Stats Canada (2007). Low Income Cut-offs for 2006 And Low Income Measures for 2005. Income Research Paper Series, Income Statistics Division of Statistics Canada, published by Ministry of Industry, May 2007.

Toronto District School Board (n.d). Demographic and Enrolment Overview. Retrieved from www.tcdsb.org/facilities\%20issues/demographics.pdf

Wayland, Sarah. V (2007). The Housing Needs of Immigrants and Refugees in Canada. A Background Paper for the Canadian Housing and Renewal Association (CHRA) through Wayland Consulting, Final Version - May, 2007.

Wen, M., Kandula, N. and Lauderdale, D. (2008). The Social and Demographic Characteristics of Ethnic Neighborhoods: Trend from 1990 to 2000. Paper presented at the annual meeting of the American Sociological Association, Montreal, 2009-05-25 from http://www.allacademic.com/meta/p105155_index.html

Zucchi , John (2007). A History of Ethnic Enclaves in Canada, Canada's Ethnic Group Series Booklet No. 31, The Canadian Historical Association. 


\section{Appendix-1: Interview Questions}

\section{Residents}

1. How long have you lived in this neighbourhood?

2. What factors influenced you to come and live in this neighbourhood?

3. Did you know about the area before moving here? If so, how?

4. What do you like about living here?

5. What you do not like about living here? What is the challenging part of living here?

6. Given all the available facilities and services, do you find this neighbourhood welcoming?

7. In what ways are you connected with the other people in this neighbourhood (family, friends, activities, community groups etc)?

8. Whom do you refer to / convey your concerns if you feel difficulty about living here?

9. What changes (positive or negative) have you seen in the neighbourhood since you came to live here?

10. Have you or your family been to any agencies/used any programs or services in this neighbourhood?

11. Are there programs, services or agencies that you would like to have access to you and your family and be available in this neighbourhood?

12. Would you refer to any of your friends and relatives at any time to come and live in this neighbourhood? If so, why?

13. What additional qualities or improvements you would like to see in this neighbourhood?

14. If at any time you decide to move from this neighbourhood, which would be your most probable favourite locations/neighbourhood? 


\section{Service Providers:}

1. What is your organization's connection with this neighbourhood and for how long?

2. What brought your organization to this area?

3. What programs and services do you offer?

4. Who currently uses your programs and services (any data about use of services)?

5. What is the percent population of this neighbourhood that uses your services?

6. What prevents the remaining population from using your services?

7. How do you monitor the population, needs and issues in the neighbourhood?

8. Do you participate in any social programs and make connections with local population?

9. What changes have you seen in the neighbourhood in recent years?

10. What are the major challenges in this neighbourhood?

11. What makes this neighbourhood welcoming?

12. In your opinion, what is the permanence rate or moving rate of this neighbourhood?

13. What would you like to see happening to improve quality of life in the neighbourhood? For what groups? 


\section{Municipal officials/staff:}

1. What are the major challenges of this neighbourhood that affect municipal services?

2. Are the demands of municipal services of this neighbourhood different from other neighbourhoods within your municipal area? How?

3. What is the factor of permanence / moving rate of this neighbourhood and how it challenges municipal services?

4. What changes / improvements do you see happening in near future in this neighbourhood from the perspective of municipal infrastructure and services?

5. The statistics shows that $x \%$ has been the rate of people moving in and $y \%$ has been the rate of moving out of this neighbourhood during the period from 2001 to 2006. Have there been any changes in the provision of municipal services (any new or any abandoned) due to such percent of movement?

6. How do you monitor the changes in neighbourhood demography?

7. What type of demographic changes have you seen in this neighbourhood from 2001 to 2006 and what is the frequency of such occurrence?

8. Do you collect and monitor longitudinal data of movements for selected homes or at neighbourhood or any other level? 


\section{Appendix-2: Demographic Tables}

Table: 1.

Thorncliffe Park

2006 Profile of Census Tracts / immigration and place of birth

$\begin{array}{rrrrrrrrr}\text { CT\# } & \text { TotalPoP } & \text { India } & \text { Sri Lanka } & \text { Guyana } & \text { Pakistan } & \text { Greece } & \text { Afghanistan } & \text { Bangladesh } \\ 194.01 & 4670 & 1395 & 130 & 0 & 1720 & 20 & 385 & 20 \\ 194.02 & 5305 & 1760 & 120 & 0 & 890 & 100 & 305 & 50 \\ 194.03 & 2805 & 435 & 55 & 0 & 175 & 110 & 135 & 15 \\ 194.04 & 4970 & 725 & 15 & 10 & 730 & 345 & 240 & 0 \\ \text { Total } & 17750 & 4315 & 320 & 10 & 3515 & 575 & 1065 & 85\end{array}$

2001 Profile of Census Tracts / immigration and place of birth

\begin{tabular}{rrrrrrrrr} 
CT\# & TotalPoP & \multicolumn{1}{c}{ India } & Sri Lanka & Guyana & Pakistan & Greece & Afghanistan & Bangladesh \\
194.01 & 5055 & 555 & 95 & 100 & 1010 & 55 & 100 & 75 \\
194.02 & 4270 & 775 & 155 & 75 & 540 & 45 & 55 & 115 \\
194.03 & 2890 & 155 & 70 & 125 & 155 & 55 & 35 & 0 \\
194.04 & 4185 & 295 & 45 & 15 & 425 & 125 & 70 & 0 \\
Total & 16400 & 1780 & 365 & 315 & 2130 & 280 & 260 & 190
\end{tabular}

Data Source:StatsCanada

Table 2.

Crescent Town

\section{Canadian Census 2006 Profile Tables/Citizenship}

CT TOTPoP China India Srilanka Pakistan AfghanistiBangladesh

$\begin{array}{rrrrrrrr}180 & 6830 & 550 & 440 & 130 & 125 & 10 & 225 \\ 190.01 & 8155 & 910 & 2410 & 235 & 520 & 70 & 1015 \\ \text { Total } & 14985 & 1460 & 2850 & 365 & 645 & 80 & 1240\end{array}$

\section{Canadian Census 2001 Profile Tables/Citizenship}

CT TOTPOP China India Srilanka Pakistan Afghanist:Bangladesh

$\begin{array}{rrrrrrrr}180 & 7085 & 285 & 85 & 85 & 245 & 60 & 365 \\ 190.01 & 9085 & 385 & 705 & 575 & 790 & 30 & 735 \\ \text { Total } & 16170 & 670 & 790 & 660 & 1035 & 90 & 1100\end{array}$


Table 3.

Milliken Neighbourhood

2006 Profile of Census Tracts / Ethnic origin and visible minorities

CT ToTPoP Chinese Indian Filipino Srilankan Pakistani Afghan Bangladesh

$\begin{array}{rrrrrrrrr}377.06 & 3720 & 3060 & 185 & 175 & 25 & 0 & 0 & 0 \\ 377.07 & 4780 & 3440 & 450 & 140 & 80 & 10 & 0 & 0 \\ 378.18 & 3005 & 1605 & 320 & 60 & 245 & 30 & 45 & 25 \\ 378.19 & 5425 & 2925 & 660 & 345 & 405 & 10 & 20 & 0 \\ 378.2 & 2155 & 1355 & 200 & 35 & 60 & 95 & 15 & 0 \\ 378.21 & 3650 & 2195 & 295 & 205 & 145 & 35 & 0 & 0 \\ 378.22 & 3405 & 2540 & 115 & 230 & 65 & 15 & 0 & 10 \\ \text { Total } & \mathbf{2 6 1 4 0} & 17120 & 2225 & 1190 & 1025 & 195 & 80 & 35\end{array}$

Canadian Census 2001 Profile Tables/Citizenship

CT ToTPoP China India Philippines Sri Lanka Pakistan Afghan Bangladesh

$\begin{array}{rrrrrrrrr}377.06 & 3615 & 2110 & 40 & 165 & 10 & 10 & 0 & 0 \\ 377.07 & 4910 & 2090 & 115 & 205 & 245 & 0 & 0 & 0 \\ 378.18 & 3075 & 1425 & 125 & 45 & 30 & 30 & 40 & 0 \\ 378.2 & 2280 & 1400 & 45 & 60 & 35 & 40 & 0 & 0 \\ 378.21 & 3730 & 1500 & 140 & 175 & 60 & 50 & 0 & 0 \\ 378.22 & 3480 & 1705 & 105 & 150 & 135 & 75 & 0 & 0 \\ 378.19 & 5600 & 805 & 295 & 355 & 340 & 120 & 0 & 0 \\ \text { Total } & \mathbf{2 6 6 9 0} & 11035 & \mathbf{8 6 5} & \mathbf{1 1 5 5} & \mathbf{8 5 5} & \mathbf{3 2 5} & \mathbf{4 0} & \mathbf{0}\end{array}$

Data Source: StatsCanada 